https://doi.org/10.47669/IHPRD-2-2019

\title{
Explaining Post-Soviet Authoritarianism in Belarus: Sources and Perspectives
}

\section{Aram TERZYAN*}

This paper explores the roots and perspectives of authoritarianism in Belarus- largely regarded as Europe's "last ditatorship" or a "nondemocratic hole in the heart of Europe" (Frear, 2019, p. 1).

Belarus is unique among the states of the former Soviet Union, in that after three decades of transition, the country remains stalled and backward - oriented. In effect, since 1994, the rule of Alexander Lukashenko in Belarus has created one of the most resilient authoritarian regimes in post-communist Europe, that shows more similarities with the republics of post-Soviet Central Asia, than with its neighbors in Europe (Rudling, 2008).

Political and economic changes are characterized by halfmeasures and compounded by excessive crackdown on civil liberties and political freedoms. Despite a broad scholarly consensus on the authoritarian nature of the Belarusian regime, its anatomy and sources remain subject to vigorous debates.

Some students contend that Lukashenko's regime is not purely autocratic given its 'democratic characteristics.' The Belarusian

\footnotetext{
* Aram Terzyan, PhD, is visiting senior lecturer at UNESCO Chair of Human Rights, Democracy and European Studies, Brusov State University of Social Sciences and Languages. Email: aramterzyan@gmail.com.
} 
commentators tend to cite the Belarusian Constitution, as an indication of the country's being democratic (Rovdo, 2009, pp. 65-66). Such contentions are consistent with and further feed Lukashenko's claims that "Democracy in Belarus is the same as in Austria, almost identical. Democratic values in Belarus are as high as in any other European country... So what is missing in the democratic portrait of Belarus? What else does Europe want from Belarus?" (Eurobelarus, 2008).

As the Turkish president Erdogan's experience suggests, the unjustified emphasis on legalism allows rule of law to be replaced by a rule by law approach, the executive prerogative principle to be dominant, and the law to be used for demobilization, all playing a critical role in the suppression of democratic opposition (Yimaz and Turner, 2019). Similarly, the Ukrainian experience shows that the Ukrainian incumbents would tend to apply the "rule by law" rather than "rule of law." Meanwhile, in conditions of systemic corruption, the law becomes a purchasable commodity (Bayramov and Marusyk, 2019, p. 80).

Alternatively, the other line of thinking suggests that the Belarusian political regime lies at the crossroads between dictatorship and democracy, thus referring to its hybrid nature. More specifically, it argued that Belarus is an electoral dictatorship or a dictatorship coexisting with a democracyinclined electorate (Korosteleva et al. 2003, pp. 14-15). Notably, Diamond (2015) calls hybrid regimes as pseudo-democratic, 'in that the existence of formally democratic political institutions, such as multiparty electoral competition, masks the reality of authoritarian domination' (Diamond, 2015). Levitsky and Way (2002) note that competitive authoritarian regimes fall short of both democracy, as well as of full-fledged authoritarianism (Levitsky and Way, 2002, p. 53). Although elections are 
Explaining Post-Soviet Authoritarianism in Belarus: Sources and Perspectives

regularly held and for the most part are free of massive fraud, incumbents invariably abuse administrative resources, creating an unlevel playing field between government and opposition (Ibid). As a result, the centralization of power, weak rule of law, along with considerable limits on political freedoms and civil liberties are common in hybrid regimes.

As a matter of fact, the electoral history of Belarus suggests that elections in Lukashenko's country are pre-determined 'contests' under the ruling elite's full control, rather than major struggles between opposition and the regime.

Other commentators contend that Belarusian regime is a demagogical democracy, wherein the national leader exerts unique influence both over politics and economy through coercing the opposition, controlling the media, as well as through relying on favoritism and populusm (Korosteleva, 2003). From this perspective, contemporary Belarus provides an insightful study of a regime that may be labelled as 'authoritarian', is simultaneously viewed as a 'demagogical democracy' following Aristotle's conceptualization of a democratic state (Ibid). 'Demagogical democracy' is associated with mass approval and reliance on the personalized power of a demagogue who governs by decree and seeks legitimation directly from the electorate (Korosteleva, 2004). Alternatively, some commentators have regarded Lukashenko's regime as facade democracy or quasi - democracy, that is far from liberal standards (Gill, 2006). 
The Belarusian regime type has been substantially influenced by its post-Soviet legacy, fraught with its economic slowdown, social inequality, weak civil society and opposition, identity crisis in nation-building and societal fragmentation (Beichelt, 2004). As a result, Belarus shows more similarities with the republics of post-Soviet Central Asia than with its neighbors in Europe (Rudling, 2008).

In effect, Belarus is an authoritarian police state wherein the opportunities to express political grievances through fair elections, democratic parliament or open media are extremely limited. As noted earlier, Belarus has never experienced a democratic transfer of power, and there is effectively no opportunity for genuine opposition candidates to gain power through elections

Not surprisingly, the political development in Belarus has been characterized by centralization of power and lack of robust political opposition. Since the ascension of President Alexander Lukashenko, the opposition has been repressed after most parliamentary and presidential elections without any substantial co-optation. As a result, the opposition has been weak and fragmented, with the ruling authorities exerting monopolistic control over civic activities. Moreover, it has not been uncommon for opposition activists to get harassed, threatened and arrested (Freedom House, 2018).

Moreover, political activism is considered risky in Belarus, given that it can result in a loss of employment, expulsion from educational institutions, smear campaigns in the media, fines, and the confiscation of property (Freedom House, 2019).

The massive crackdown on civil society and political freedoms has much to do with Lukashenko's counter-revolution policies. More 
Explaining Post-Soviet Authoritarianism in Belarus: Sources and Perspectives

specifically, in the wake of the 2004 Orange Revolution unfolding in neighboring Ukraine, Lukashenko embarked on further tightening his grip on power, not least through increasing the Belarusian KGB's involvement in domestic politics. More specifically, in January 2005, Lukashenko appointed General Stepan Sukhorenka as the new KGB head and made it clear that he expected the KGB to play a more active role in monitoring societal developments (Forbig, et al, 2006).

Moreover, in 2006 the Belarusian parliament amended the Law "On Interior Ministry Troops of Belarus" thus empowering internal security troops to disperse anti-government demonstrations (Ibid). Parliament granted the president the right to order Belarusian troops to use weapons and other military equipment to maintain domestic order. The right of Belarusian servicemen to refuse to follow what they deemed to be an illegal order, such as refusal to shoot at or use military vehicles against civilians, was restricted. Furthermore, Belarusian military, and police personnel, henceforth, had to swear allegiance to Lukashenko rather than to the Republic of Belarus or to its constitution. Clearly, this aimed at lowering the likelihood of units defecting to the political opposition. The police, military, and security apparatus at the disposal of Lukashenko is immense, comprised of at least 110,000 paramilitary forces, including the special police (Otryad Militsii Osobovo Naznacheniya, or OMON), which can be supplemented with huge number of reserves (Ibid).

As for 2010 there were 325 police personnel for 100 thousand people, which is deemed to be quite high by international standards (Harrendorf et 
al, 2010). Evidently, such an outsized security apparatus aims at serving as Lukashenko's power base in the absence of significant public support in his favor.

Remarkably, it is not uncommon for commentators to emphasize the totalitarian nature of the Belarusian regime. As argued by Shushkevich, the ex-speaker of the Belarussian Parliament, Belarus returned to the neocommunist dictatorship, with somewhat tolerant attitude towards civil society (Shushkevich, 2003).

A comparative analysis of post-communist regimes prompts Matsuzato (2004) to suggest that unlike Russian, Ukrainian, and even Central Asian political regimes, which are characterized by a pluralistic competition between clans, Belarusian clan policy is monopolistic. Enhancing only his own clan and establishing electoral falsification mechanisms, Lukashenko rules out any competition with other fractions. He has managed to suppress all the challenging clans, whether parliamentary, bureaucratic, financial-oligarchic, industrial, or regional (Matsuzato, 2004). Besides this, populism and anti-elitism, which have significantly contributed to Lukashenko's rise to power, has become of systematic and permanent nature. Lukashenko's successful clan politics is justified under the auspices of populist politics, wherein only two players exist: the leader and the people (Ibid).

Notably, some students would go so far as to treat Lukashenko's regime as sultanic, not least given its ideological foundations and the ruling elite's immense dependence on its leader (Eke et al, 2000). By contrast, other commentators avoid regarding the Belarusian regime as sultanic, given the variations of severity and scale of human rights violations in typical sultanic Central Asian countries and Belarus (Ioffe, 2004). Put 
Explaining Post-Soviet Authoritarianism in Belarus: Sources and Perspectives

simply, the state of human rights in Belarus is less abysmal as that in typical sultanic regimes.

In sum, despite diverging explanations of the anatomy of the Belarusian regime, its durability considerably owes to Lukashenko's ability to sustain his power by preserving elite unity, controlling elections, and/or using force against opponents.

\section{Russian authoritarian influence}

Of all former Soviet bloc countries, Belarus is most vulnerable to the Russian influence, with the two countries forming a union state being members of the same defense and economic communities.

Under the Lukashenko's regime, Belarus has become linked with Russia through a multitude of bilateral treaties and agreements covering virtually all areas of inter-state action. As a result, Russia's relationship with Belarus is closer than that of any other former USSR country. Ambrosio (2006), notes that the situation in Belarus is such that the external factors that have proved to promote democratization have been weakened or undermined by its relationship with Russia in general, and by the proposed Russia-Belarus union in particular (Ambrosio, 2006).

Russian leaders, including Putin, have consistently legitimized Lukashenko's rule both diplomatically and politically, not least through defending Belarus's unfair and unfree elections. In the economic realm, Russia-Belarus trade and Russian subsidies shield Belarus from any possible trade sanctions from Western Europe, thus sustaining the regime's unreformed economic system (Ambrosio, 2006). 
Meanwhile, the chances of democratic state-building in the Russian orbit of influence are extremely limited.

Diuk (2014) analyzes the harrowing challenges facing the post-Cold War order in Europe, and posits that the chances of democratization across a vast swath of Eurasia seem slimmer now, than ever before in the face of Russian President Vladimir Putin's crackdown on liberal-democratic forces at home and abroad (Diuk, 2014, p. 83). Such claims are not novel. Conventional logic posits that the Kremlin has a strong interest in ensuring that regional and global democratic trends do not affect grip on the Russian political system and that the legitimacy of democracy promotion and regime change are subverted (Roberts and Ziemer, 2018). This line of thinking presumes that Russia poses threats to liberal democracies by rolling back democracy around the world and bringing down democratic governments in its neighborhood and beyond (Ambrosio, 2007). Shevtsova (2014) notes that the pro-EU, democratic movement in Ukraine heightened Putin regime's fears about its possible spillover into Russia, amid lingering concerns about recurrence of large-scale post-election protests that erupted in 2011. In response, Putin resorted to reinforcing personalistic leadership, sparing no effort to undermine Western influence over its "near neighborhood" (Shevtsova, 2014, p. 74). Thus, Shevtsova concludes that the crisis in Ukraine stems from Russia's struggle to control Ukraine and keep it in the orbit of its authoritarian influence, as opposed to the Ukrainians" "choice for Europe" (Ibid). Such an antagonism comes down to the evolution of the Kremlin's foreign policy thinking during Vladimir Putin's presidency, that led to the establishment of an opposing ideology to the Western/European one based on Russian ethnic nationalism, conservative values and the Russian Orthodox church. This new ideology 
Explaining Post-Soviet Authoritarianism in Belarus: Sources and Perspectives

and the increasingly anti-western rhetoric contributes significantly to substantial othering of Russia and its portrayal as Europe's "Other" in European political thinking (Neumann, 2016). As a result, Russia is increasingly defining itself as a rival to the EU with the creation of the Eurasian Union and thus strives construct a Eurasian identity (Stefánsson, 2015). In this regard the Maidan Revolution can be viewed as a manifestation of "clash of civilizations" between European and Eurasian projects that confirmed Ukraine's "choice for Europe." The Ukrainian revolution is deemed to herald the end of the post-Cold war settlement that vanished the hopes of Euro-Russian integration (Shevtsova, 2014, p. 74). That said, instead of joining the Western civilization, Russia positioned itself as its "Other" and resorted to what Delcour and Wolczuk refer to as alternative region building or region-spoiling measures aimed at securing its regional hegemony (Delcour and Wolczuk, 2017).

Overall, while the EU is largely viewed as peace and democracy promoter, Russia is seen as its ideological rival, that strives to produce autocracies in post-Soviet countries with the view to absorbing them into its ranks. Meanwhile, as noted earlier, the Russian policy towards its 'near neighborhood' has been broadly associated with 'authoritarian resistance', 'authoritarian diffusion' and 'democracy prevention' (Von Soest, 2015; Finkel and Brudny, 2012). That said, the chances of fundamental democratic reforms in Belarus are extremely limited as long as the country remains in the orbit of the Russian influence. 
In sum, the main characteristics of the Belarusian authoritarianism range from centralization and personalization of power to extensive crackdown on civil liberties and political freedoms.

Under Lukashenko's presidency Belarus shifted to a hyper presidential system, finding itself in a situation where the President had immense power to make strategic domestic and foreign policy choices single-handedly. By using his hyper-presidential power, Lukashenko has controlled institutions and the political system, coerced the opposition, built-up security forces and pro-regime groups. Besides, he launched a crackdown on independent media, while suppressing dissent across the country. Not surprisingly, Belarus gained centrality in Russia-led sociopolitical order that appears conducive to sustaining Lukashenko's authoritarian rule.

\section{References}

Ambrosio, T. (2006). The Political Success of Russia-Belarus Relations: Insulating Minsk from a Color Revolution. Demokratizatsiya, 14(3), pp. 407-434.

Ambrosio, T. (2007). Insulating Russia from a colour revolution: How the Kremlin resists regional democratic trends. Democratisation, 14(2), pp. 232-252.

Bayramov, A. and Marusyk, Y. (2019). Ukraine's unfinished natural gas and electricity reforms: one step forward, two steps back. Eurasian Geography and Economics, 60(1), pp. 73-96.

Beichelt, T. (2004). Autocracy and Democracy in Belarus, Russia and Ukraine. Democratization, 11 (5), pp. 113-132.

Delcour, L. and Wolczuk, K. (2016). Between the Eastern Partnership and the Eurasian Economic Union: Competing region-building projects in the 'common neighbourhood'. In Theorizing the European neighbourhood policy (pp. 211-230). Routledge.

Diamond, L. (2015). In search of democracy. Routledge. 
Explaining Post-Soviet Authoritarianism in Belarus: Sources and Perspectives

Diuk, N. (2014). The Maidan and Beyond: Finding Ukraine. Journal of Democracy, 25(3), 83-89.

Eke, S. M. and Kuzio, T. (2000). Sultanism in Eastern Europe: the socio-political roots of authoritarian populism in Belarus. Europe-Asia Studies, 52(3), pp. 523-547.

Eurobelarus (2008). President Lukashenko: Democracy in Belarus Matches Democracy in Austria. Retrieved October 23, 2019 from https://en.eurobelarus.info/news/archive/2008/03/21/presidentlukashenko--democracy-in-belarus-matches-democracy-in-austria.html.

Finkel, E. and Brudny, Y. M. (2012). Russia and the Colour Revolutions. Democratization, 19(1), pp. 15-36.

Forbrig, J., Marples, D. R. and Demeš, P. (Eds.). (2006). Prospects for democracy in Belarus. German Marshall Fund of the United States.

Frear, M. (2019). Belarus under Lukashenka: Adaptive Authoritarianism. Routledge.

Freedom House (2019). Belarus. Retrieved December 23, 2019, from https://freedomhouse.org/country/belarus/freedom-world/2019.

Freedom House. (2018). Belarus. Retrieved October 29, 2019, from https://freedomhouse.org/country/belarus/freedom-world/2018.

Gill, G. (2006). Nationalism and the Transition to Democracy. The Post-Soviet Experience. Demokratizatsiya, 14 (4). pp. 613 - 626.

Harrendorf, S., Heiskanen, M., Malby, S. (2010). International Statistics on Crime and Justice. Retrieved October 22, 2019 from http://www.unodc.org/documents/data-and-analysis/Crimestatistics/International_Statistics_on_Crime_and_Justice.pdf.

Ioffe, G. (2004). Understanding Belarus: economy and political landscape. Europe-Asia Studies, 56(1), pp. 85-118.

Korosteleva, E. A. (2003). Is Belarus a demagogical democracy?. Cambridge Review of International Affairs, 16(3), pp. 525533. 
Korosteleva, E. A. (2004). The quality of democracy in Belarus and Ukraine. Journal of Communist Studies and Transition Politics, 20(1), pp. 122-142.

Korosteleva, E., Lawson, C. and Marsh, R. (Eds.). (2003). Contemporary Belarus: between democracy and dictatorship. Routledge.

Levitsky, S. and Way, L. A. (2002). Elections without democracy: The rise of competitive authoritarianism. Journal of democracy, 13(2), 5165 .

Matsuzato, K. (2004). A populist Island in an Ocean of Clan Politics: The Lukashenka Regime as an Exception among CIS Countries. EuropeAsia Studies, 56(2), pp. 235-261.

Neumann, I. B. (2016). Russia and the Idea of Europe: A Study in Identity and International Relations. Taylor \& Francis.

Roberts, S. and Ziemer, U. (2018). Explaining the pattern of Russian authoritarian diffusion in Armenia. East European Politics, 34(2), pp. 152172.

Rovdo, V. (2009). Comparative Political Science. In 3 parts. Part 3. The Political System of the Republic of Belarus (Сравнительная политология. В 3 частях. Часть 3. Политическая система Республики Беларусь). European Humanitarian University. Vilnius.

Rudling, P. A. (2008). Belarus in the Lukashenka era: National identity and relations with Russia. In Europe's Last Frontier? (pp. 55-77). Palgrave Macmillan, New York.

Shevtsova, L. (2014). The Maidan and Beyond: The Russia Factor. Journal of Democracy, 25(3), pp. 74-82.

Shushkevich, S. (2003). Belarus: to democracy through neocommunism. Demokratizatsiya, 11(1), pp. 55 -63.

Stefánsson, V. (2015). Is Russia Europe's Other? How the Ukraine Crisis Reinforces European Identity Formation (Doctoral dissertation). $\begin{array}{llll}\text { Retrieved } & \text { April } & 2819 & \text { from }\end{array}$ https://skemman.is/bitstream/1946/22766/3/Is\%20Russia\%20Europe\%27 s\%20Other\%20Skemman-PDF.pdf . 
Explaining Post-Soviet Authoritarianism in Belarus: Sources and Perspectives

Von Soest, C. (2015). Democracy prevention: The international collaboration of authoritarian regimes. European Journal of Political Research, 54(4), pp. 623-638.

Y1lmaz, Z. and Turner, B. S. (2019). Turkey's deepening authoritarianism and the fall of electoral democracy. British Journal of Middle Eastern Studies, 46 (5), pp. 691-698. 